\title{
WIESŁAW PRZYGODA \\ Apostolat świeckich w Polsce w czterdzieści lat po Soborze Watykańskim II
}

Dnia, 8 grudnia 2005 r. minęlo 40 lat od zakończenia Soboru Watykańskiego II. Dystans czasowy dzielący nas od tego wydarzenia upoważnia do refleksji nad stanem recepcji dziela soborowej odnowy Kościola w wymiarze powszechnym i lokalnym. W przeszłości, w zależności od rodzajów uchwal soborowych, istnialy dwa rodzaje ich recepcji. Recepcja uchwal doktrynalnych polegala na ich zrozumieniu i przyjęciu jako autentycznej wykladni prawdy objawionej. Natomiast recepcja uchwal o charakterze dyscyplinarnym polegala na wprowadzeniu zmian w strukturze organizacyjnej Kościola oraz w życiu i postępowaniu wiernych ${ }^{1}$. Sobór Watykański II odróżnial się od poprzednich soborów powszechnych przede wszystkim swym pastoralnym charakterem. Stąd w ocenie recepcji tego soboru należy koncentrować się na odnowie struktur duszpasterskich Kościoła, a także na odnowie świadomości i postępowania wiernych.

Celem tego artykułu jest refleksja nad stanem soborowego aggiornamento w zakresie apostolatu świeckich w Polsce. Przypomniane zostana tu najpierw istotne rysy soborowej teologii laikatu i apostolstwa. Ponieważ Sobór Watykański II wskazal na świat i Kościól jako miejsca realizacji apostolstwa świeckich, w drugiej części artykułu zostanie podjęta próba ukazania zaangażowania apostolskiego katolików polskich w życiu spolecznym i kościelnym. Będzie to prezentacja bardziej demonstratywna niż wyczerpująca, gdyż calościowe opracowanie wymagałoby przeprowadzenia rozległych i kosztownych badań socjologicznych. Zadaniem teologii pastoralnej jest ukazywanie Kościołowi dróg na przyszlość,

${ }^{1}$ J. K r u k o w s k i: Recepcja Soboru Watykańskiego II a struktury kościelne w Polsce. W: W dwudziestolecie Soboru Watykańskiego II. Recepcja - doświadczenia - perspektywy. Red. J. Ho merski, F. S z u lc. Lublin 1987 s. 120. 
dlatego zostanie także podjęta próba wskazania perspektyw apostolatu świeckich w Polsce w najbliższej przyszlości.

\section{Teologia laikatu i apostolstwa w dokumentach Soboru Watykańskiego II}

Sobór Watykański II przewartościowal sposób postrzegania miejsca i roli świeckich we wspólnocie Kościoła oraz ich zadań apostolskich w świecie, co bylo już wcześniej postulowane przez wielu teologów (Y. Congar, J. Cardijn, K. Rahner, F. Klostermann, F.X. Arnold, G. Thils, G. Philips, A. Auer, H.U. von Balthasar, E. Schillebeeckx) ${ }^{2}$. W reprezentatywnym dla świadomości teologicznej końca XIX wieku niemieckojęzycznym Kirchenlexikon pod hasłem „laik” znajdowal się tylko odnośnik do hasła „kler”, w którym laika określano jako nieduchownego ${ }^{3}$. Kodeks Prawa Kanonicznego z 1917 r. stanowil, że: „z ustanowienia Chrystusa święcenia odróżniają w Kościele duchowieństwo od ludzi świeckich - dla rządzenia wiernymi oraz dla wykonywania kultu Bożego" (kan. 948). W komentarzach prawnych do tego kodeksu przeważalo negatywne określenie laikatu w Kościele. Przykladem tego jest definicja wiernego świeckiego, jaką podali w swoim komentarzu A. Vermeersch i J. Creusen: „Laikiem jest ten, kto w żaden sposób nie uczestniczy w jurysdykcji a przede wszystkim we władzy święceń" ". Dla Y. Congara był to swoisty skandal, że przed Soborem Watykańskim II wiadomo bylo, kim laik nie jest - natomiast nie wiadomo bylo, kim on jest w Kościele ${ }^{5}$. Dlatego jako jeden z pierwszych teologów usiłował wypracować pozytywne określenie laikatu. To pokazuje, jak pilnie potrzebna byla soborowa odnowa teologii laikatu, która uwydatniła idę̨ apostolstwa podejmowanego przez chrześcijan świeckich z ich inicjatywy i na wlasną odpowiedzialność, utożsamiajacego się w pewnym sensie $\mathrm{z}$ ich życiem chrześcijańskim ${ }^{6}$.

Dyskusja soborowa na temat roli i miejsca laikatu w Kościele była wymuszona wielkimi przemianami w świecie, jakie dokonaly się po II wojnie światowej. Proces sekularyzacji, rozwój nowoczesnych środków komunikacji, a także

${ }^{2}$ Zob. L. K a rre r. Die Stunde der Laien. Von der Würde eines namenlosen Standes. Freiburg-Basel-Wien 1999 s. 146-153.

${ }^{3}$ Kirchenlexikon. Hrsg. H.J. W e tze r, B. We 1 te. Freiburg 1891. Bd. 3 s. 546; zob. H. F i 1 s e r. Das Dekret über das Laienapostolat. Apostolicam actuositatem. W: Vierzig Jahre II. Vatikanum. Zur Wirkungsgeschichte der Konzilstexte. Hrsg. F.X. B i s c h o f, S. L e i m g r u b e r. Würzburg 2004 s. 252.

${ }^{4}$ A. Vermeers c h, J. C re us e n. Epitome Iuris Canonici. Mecheln-Rom 1927. T. $1 \mathrm{nr}$ 199; cyt. za: E. W e ro n. Laikat i apostolstwo. Paris 1973 s. 13.

${ }^{5}$ Y. C o n g a r: Jalons pour une théologie du lä̈cat. Paris 1964 s. 37.

${ }^{6} \mathrm{~A} . \mathrm{Z}$ u b e r b i e r: Wprowadzenie do Dekretu o apostolstwie świeckich. W: Sobór Watykański II. Konstytucje, dekrety, deklaracje. Poznań $1986^{3}$ s. 369. 
malejąca liczba księży stymulowały liczne dyskusje o pozycji laikatu w Kościele, a także o stosunku Kościola do świata i sposobach realizacji jego zbawczej misji w świecie wspólczesnym. Owocem tej dyskusji byla soborowa koncepcja Kościoła jako Ludu Bożego, w którym nie tylko hierarchia, lecz także katolicy świeccy odgrywaja decydujaca rolę i ponosza odpowiedzialność za realizację posłannictwa zbawczego $\mathrm{w}$ świecie. Ożywiona dyskusja soborowa wokól roli katolików świeckich byla kontynuowana po soborze, a do jej szczególnych owoców należą posynodalne adhortacje apostolskie: Evangelii nuntiandi, Catechesi tradende, Familiaris consortio, Christifideles laici.

Przesłanki do teologii i praktyki apostolstwa świeckich zawieraja niemalże wszystkie dokumenty Soboru Watykańskiego II. Fundamentalne prawdy na temat apostolstwa świeckich zostaly wyrażone jednak w trzech dokumentach soborowych. Wprowadzenie doktrynalne zostalo umieszczone w Konstytucji dogmatycznej o Kościele, wskazania do działalności spolecznej katolików zostaly przedstawione w Konstytucji duszpasterskiej o Kościele w świecie współczesnym, a pozostałe przesłanki na temat apostolstwa świeckich zostaly zawarte w Dekrecie o apostolstwie świeckich. W ostatnim z wymienionych dokumentów ojcowie soborowi starali się przedstawić naturę apostolstwa świeckich, unikając ducha klerykalizmu oraz pozostawiając znaczną otwartość w zakresie praktycznych form $\mathrm{i}$ inicjatyw apostolskich.

Wypracowane przez Sobór Watykański II określenie czlowieka świeckiego zostalo wyrażone $\mathrm{w}$ formie opisu typologicznego ${ }^{7}, \mathrm{z}$ którego latwo wyodrębnić elementy stanowiące istotę czlowieka świeckiego w Kościele. Świeccy, to przede wszystkim ludzie ochrzczeni, a chrzest jest źródłem sakralnego charakteru calego Ludu Bożego. Stąd za św. Pawłem można powiedzieć, że świeccy to „wybrańcy Boży, święci i umilowani” (Kol 3, 12; zob. Rz 1,7). Na skutek wszczepienia w Chrystusa wierni świeccy w sposób sobie właściwy uczestniczą w kaplańskim, prorockim i królewskim urzędzie Chrystusa. Korzystając z przysługujących im uprawnień, chrześcijanie świeccy realizują posłannictwo w Kościele i świecie.

${ }^{7}$ Pod nazwa swiecki rozumie sie wszystkich wiernych chrześcijan nie bedacych czlonkami stanu kaplańskiego i stanu zakonnego [...], którzy jako wcieleni przez chrzest w Chrystusa, ustanowieni jako Lud Boży i uczynieni na swój sposób uczestnikami kaplańskiego, prorockiego i królewskiego urzędu Chrystusowego, ze swej strony sprawuja wlaściwe catemu ludowi chrześcijańskiemu postannictwo w Kościele i świecie. Wlaściwościa specyficzna laików jest ich charakter świecki. [...] Zadaniem ludzi świeckich, z tytulu wlaściwego im powolania, jest szukać Królestwa Bożego zajmujac sie sprawami świeckimi i kiemijac nimi po myśli Bożej. Żyja oni w świecie [...]. Tam ich Bóg powoluje, aby wykonujac wlaściwe sobie zadania, kierowani duchem ewangelicznym przyczyniali się do uświęcania świata na ksztalt zaczynu, od wewnątrz niejako, $i$ w ten sposób przykladem zwlaszcza swego życia promieniujac wiara, nadzieja i milościa, ukazywali inmym Chrystusa (KK 31) 
Specyficznym przymiotem wiernych świeckich jest ich charakter świecki. Ludzie świeccy, w przeciwieństwie do kaplanów i zakonników, z woli Bożej pozostaja $w$ świecie. Nie jest to dzielem przypadku, ani brakiem powolania do rzeczy wyższych, ale jest czymś zaplanowanym i zamierzonym przez Boga. Jest to zatem stan w Kościele, czyli pewien staly sposób życia i uświęcania się. Pozostawanie w świecie katolików świeckich polega na realizacji w zwyklych warunkach świata obowiązków życia rodzinnego i społecznego. To zaś wplywa na psychikę i ksztaltuje specyficzna duchowość czlowieka świeckiego. Ludzie świeccy poprzez pracę zawodową i zaangażowanie spoleczno-polityczne i gospodarcze wchodzą dogłębnie w sprawy doczesne, ksztaltują oblicze świata i rozwijają kulturę. Jako ochrzczeni mają uświęcać doczesność i wprowadzać wartości ewangeliczne w rzeczywistość świecką.

Zadaniem katolików świeckich jest uświęcać świat od wewnątrz. To jest ich świeckie powolanie, które istnieje obok powolań do życia kaplańskiego i konsekrowanego. Ludzie świeccy moga uzdrowić i uświęcić od wewnątrz życie rodzinne, ekonomiczne, spoleczne, polityczne, kulturalne itd. Duchowni na ogól mają do tych dziedzin dostęp ograniczony. Tak więc dzielo uświęcenia świata jest w swej istocie domeną katolików świeckich. Oni mają stanowić zaczyn ewangeliczny, który przemieni świat i nasyci wartościami chrześcijańskimi cala ludzkość ${ }^{8}$.

Przez apostolstwo katolicy świeccy wlączają się w realizację zbawczej misji Kościola. Do uczestnictwa w misji Kościoła upoważnia katolików przyjęcie sakramentów inicjacji chrześcijańskiej, które profilują życie katolików świeckich na zadania wynikające $\mathrm{z}$ ich chrześcijańskiego powolania. Chrzest odradza do życia dziecka Bożego i jest źródłem jedności z Chrystusem i Kościołem. Sakrament bierzmowania uwypukla pozytywną stronę uświęcenia oraz zapewnia moc Ducha Świętego w świadczeniu o Chrystusie (KK 33). Eucharystia daje wewnętrzną moc do doskonalenia miłości i świętości. Dla wielu katolików świeckich także sakrament malżeństwa staje się podstawą konkretyzacji powołania i dzialalności apostolskiej. Czlowiek świecki staje się uczestnikiem posłannictwa Kościola także na mocy charyzmatów, jakie otrzymal od Ducha Świętego (KK 33). Z ich przyjęcia przez katolika wynika prawo i obowiązek używania ich w Kościele i świecie (DA 3). Charyzmaty przyczyniaja się do budowania Kościola, powiększania dobra wspólnego i zaspokajania potrzeb ludzi. Żaden charyzmat nie zwalnia z obowiązku poshuszeństwa wobec hierarchii Kościoła.

\footnotetext{
${ }^{8}$ W e r o n, jw. s. $18-20$; zob. H. Urs v on B alth a s a r, L. Gi u s s an i. Miejsce chrześcijanina w świecie. Kraków 2003 s. 117-184; J. G o c k o. Kościól obecny w świecie - postany do świata. Lublin 2003 s. 366-386.
} 
Apostolstwo świeckich wynika z natury Kościola, którego katolicy świeccy stanowią integralną część. Kościól ma charakter wspólnotowy i misyjny. Pod zwierzchnictwem biskupów Kościól realizuje odwieczny plan Ojca, w zjednoczeniu z Chrystusem i w mocy Ducha Świętego (zob. KK 4). Kościól wypełnia zbawcza wolę Boga, któremu spodobalo się ,uświęcać i zbawiać ludzi nie pojedynczo, lecz we wspólnocie" (KK 9). Jako wybrany Lud Boży, wszyscy wierni stanowią jedno cialo w Chrystusie. Kościelna wspólnota odznacza się wspólistnieniem wielorakich powołań, charyzmatów i zadań, które, choć różne, są względem siebie komplementarne. Jeden Duch Święty stanowi bowiem dynamiczną zasadę jedności i różnorodności Kościoła (KK 7).

We wspólnocie Kościola nie ma zróżnicowania w godności ludzi świeckich i hierarchii. Kościól posiada wprawdzie strukturę hierarchiczną, ale jest ona calkowicie podporządkowana świętości członków Chrystusowego Ciala. „W Królestwie niebieskim najważniejsze miejsce zajmuja nie szafarze, lecz święci"”. W Kościele różne stany życia są ściśle ze sobą związane i uzupelniają się w dzialalności apostolskiej. Wszyscy pracują w jednej winnicy Pańskiej, realizując różne, dopelniajace się wzajemnie charyzmaty i posługi. Poprzez różnorodność powolań Kościól objawia i przeżywa nieskończone bogactwo tajemnicy Jezusa Chrystusa (zob. KK 4; 7 ).

Kościół z natury jest misyjny, ponieważ zostal powołany po to, aby szerząc królestwo Boże na ziemi, uczynić wszystkich ludzi uczestnikami zbawczego odkupienia i skierować świat do Chrystusa. Wszelka dzialalność Kościola zmierzajaca do tego celu jest apostolstwem. Toteż każdy czlowiek należący do Kościoła powinien angażować się w działalność apostolska, bo w żywym organizmie żaden czlonek nie zachowuje się biernie, lecz spelnia konieczną dla życia organizmu funkcję. Dlatego obok duchowieństwa i zakonników również katolicy świeccy sa przez Boga powolani do tego, aby przyczyniali się do wzrastania i uświęcania Kościoła (zob. KK 33).

\section{Kościól i świat miejscem realizacji apostolstwa świeckich}

Apostolstwo świeckich polega na uczestnictwie świeckich w zbawczym poslannictwie Chrystusa przez realizację zadań apostolskich w Kościele i świecie. Sobór Watykański II przyczynił się do przezwyciężenia niekorzystnego dla katolików świeckich rozróżnienia „,poshuga zbawcza” - ,posluga światu” (Heilsdienst - Weltdienst) oraz przypisywania pierwszej wylącznie duchowieństwu a drugiej

\footnotetext{
${ }^{9}$ Kongregacja Nauki Wiary. Deklaracja $w$ sprawie dopuszczania kobiet do kaplaństwa urzędowego ,,Inter insigniores”. 15 X 1977. AAS 69:1977 s. 115.
} 
tylko świeckim. Wszyscy chrześcijanie mają bowiem do spelnienia odpowiednie do swego powolania zadania zarówno w Kościele, jak i w świecie ${ }^{10}$.

Miejscem realizacji apostolstwa świeckich jest zatem Kościól (KK 33). Apostolstwo polega bowiem na uczestnictwie w zbawczej misji Kościola i realizacji potrójnej funkcji Chrystusa. Uczestnictwo w funkcji kapłańskiej, prorockiej i królewskiej Chrystusa jest uwarunkowane przynależnościa do Kościoła (ChL 14). W parafiach dzialalność świeckich jest do tego stopnia konieczna, że bez niej apostolstwo duszpasterzy nie byłoby w pelni skuteczne (zob. DA 10).

Apostolstwo katolików polega na realizacji funkcji liturgicznej. Sobór Watykański II wskazal na dwa zwiazane ze soba sposoby realizacji tej funkcji: uczestnictwo w sakramentach świętych oraz calkowite oddanie swojej egzystencji Bogu (KK 11). Chrzest upoważnia katolików świeckich do sprawowania kultu Bożego, a zwlaszcza do uczestnictwa w Eucharystii i innych sakramentach. Szczególną rolę w uświęceniu życia świeckich odgrywa sakrament malżeństwa, którego sami świeccy są szafarzami. Malżeństwo i rodzina stwarzaja przestrzeń do rozwijania wlasnego apostolstwa świeckich. W konsekwencji przyjęcia chrztu nic w życiu chrześcijanina nie powinno się wymykać spod wplywu Chrystusa. Toteż wierni świeccy realizuja apostolstwo, gdy z Nim, w Nim i przez Niego skladają „ciala swoje na ofiarę żywa, święta, Bogu przyjemna” (Rz 12, 1), a „Wszystkie ich uczynki, modlitwy i apostolskie przedsięwzięcia, życie malżeńskie i rodzinne, codzienna praca, wypoczynek ducha i ciala, [...] stają się duchowymi ofiarami, milymi Bogu przez Jezusa Chrystusa" (KK 34).

Sobór Watykański II wskazal trzy komplementarne sposoby realizacji funkcji profetycznej przez ludzi świeckich: świadectwo życia, gloszenie Ewangelii i charyzmaty dane ku zbudowaniu wspólnoty. Świadectwo życia chrześcijańskiego przyczynia się do postępu ewangelizacji Kościoła oraz do odnowy świata w duchu Chrystusowym. Jest wiele miejsc i okoliczności, w których tylko dzięki ludziom świeckim orędzie Ewangelii i przesłanie Kościola może docierać (zob. KK 33). Przez świadectwo wiary świeckich Kościół nawiazuje zbawczy dialog z ludźmi nie znającymi Chrystusa. Obok świadectwa życia potrzebne jest także świadectwo slowa (DA 16). Dotyczy to sytuacji, kiedy milczenie byloby równoznaczne z zaparciem się wiary oraz, gdy w grę wchodzi sprawa wiecznego zbawienia bliźnich. Szczególną rolę w ewangelizacji pelni rodzina chrześcijańska, która powinna być szkolą pobożności i miejscem pierwszych czynów apostolskich. Malżonkowie są powolani do świadectwa wiary i milości chrześcijańskiej wobec siebie nawzajem, swoich dzieci i innych rodzin (KK 35 ).

${ }^{10}$ Zob. Fils er, jw. s. 261. 
Katolikom świeckim przysługuje również udzial w funkcji królewskiej Kościoła. Chrystus przez służbę ludziom i posłuszeństwo Ojcu aż do śmierci wszedl do chwaly swego królestwa. Dlatego również Jego uczniowie powinni posiąść „stan królewskiej wolności przez zaparcie się siebie i życie święte” (KK 36). Chrześcijańska królewskość polega na duchowej walce, majacej na celu pokonanie w sobie królestwa grzechu. Katolicy świeccy są wezwani także do tego, aby milością i służbą przywracać stworzeniu jego pierwotną wartość, a ludzką kulturę przepajać wartościami chrześcijańskimi. Świadectwo Chrystusa zobowiazuje katolików do zaangażowania się w budowanie cywilizacji milości. Przez modlitwę, styl życia, braterskie upomnienie, poshuge charytatywna katolicy prowadza innych do lączności z Chrystusem w Kościele. Świadectwo milości i braterstwa stanowi ważny wymiar apostolstwa świeckich, ponieważ jest formą przepojenia duchem chrześcijańskim porządku doczesnego (DA 2; zob. ChL 41).

Na podstawie misji kanonicznej katolicy świeccy mogą uczestniczyć w niektórych zadaniach wlaściwych hierarchii, np. w gloszeniu nauki chrześcijańskiej, pelnieniu czynności liturgicznych i opiece duszpasterskiej (zob. DA 24; ChL 23). Ponieważ te zadania związane są z misją duszpasterzy, świeccy podlegają ich kierownictwu i muszą się starać, by zachować „odrębność zarówno natury i misji posługi kapłańskiej, jak i powolania oraz świeckiej natury laikatu"11.

Kodeks Prawa Kanonicznego z 1983 r. precyzuje, jakie poslugi, urzędy i funkcje moga być powierzane, na mocy misji kanonicznej, katolikom świeckim. W sytuacji wyższej konieczności Kościoła, zwlaszcza ze względu na brak szafarzy, ludzie świeccy moga w ich zastępstwie pelnić poslugę słowa, przewodniczyć modlitwom liturgicznym, udzielać chrztu, a także Komunii świętej (kan. 230 §; kan. $910 \S 2$ ). Katolicy świeccy mogą być dopuszczeni do wspóludzialu w trosce duszpasterskiej o parafię pozbawioną proboszcza (kan. 517 \& 2); mogą otrzymać prawo udzielania chrztu przy nieobecności duszpasterzy (kan. $861 \S 2$ ); wystawienia Najświętszego Sakramentu (kan. 943); asystowania przy zawieraniu malżeństw (kan. 1112). Do biskupa diecezjalnego należy władza udzielania wiernym świeckim misji kanonicznej do wykonywania wymienionych czynności w Kościele. Misja kanoniczna upoważnia katolików świeckich do nauczania religii we wszystkich typach szkól (kan. $229 \S 3 ; 759 ; 776$ ). W nauczaniu za pośrednictwem radia lub telewizji należy stosować przepisy wydane przez konferencje biskupów (kan. $772 \S 1$ ). Profetyczna misja świeckich może być ponadto realizowana poprzez zawodowe uprawianie teologii.

${ }^{11}$ Instrukcja o niektórych kwestiach dotyczacych wspólpracy wiernych swieckich w ministerialnej poshudze kaplanów. 15 VIII 1997. „L'Osservatore Romano”. Wydanie polskie. R. 19: 1998 nr 12 s. 31. 
Zadanie odnowy porząku doczesnego jest zadaniem calego Kościola. Obowiązkiem duszpasterzy jest jasne przedstawianie celu stworzenia, zasad używania rzeczy doczesnych oraz wydawanie sądów o zgodności działalności świeckich z zasadami moralnymi (DA 24). Natomiast katolicy świeccy powinni podejmować zadanie odnowy porzadku doczesnego w sposób bezpośredni i na własna odpowiedzialność (DA 7). Sa bowiem takie miejsca i okoliczności, w których tylko dzięki ich pomocy laska Boża może być przekazywana, a Kościól może stawać się solą ziemi (KK 33). Porządek spraw doczesnych należy odnawiać w taki sposób, aby nie naruszając jego praw, uzgodnić go z normami życia chrześcijańskiego oraz dostosować do różnych warunków miejsca, czasu i narodów (DA 7).

Apostolstwo świeckich w świecie odnosi się nie do rzeczy, lecz do ludzi w wymiarze indywidualnym i spolecznym. Dlatego odnowa porządku doczesnego rozpoczyna się od uświadomienia nienaruszalnej godności osoby ludzkiej (ChL 37). Podstawowe zadanie świeckich wobec spoleczności ludzkiej polega na tym, aby ukazywać absolutną wartość czlowieka, którego Bóg chciał dla niego samego (KDK 24) i który jest pierwszą i podstawową drogą Kościola (RH 14). Katolicy świeccy mają bronić prawa do życia, które przysluguje czlowiekowi od chwili poczęcia aż do naturalnej śmierci (zob. KDK 27; ChL 38). Prawo do życia jest gwarancja pozostalych praw czlowieka. Do istoty apostolatu świeckich należy uświęcanie świata, a szczególnie sfery życia malżeńskiego i rodzinnego, ekonomii i gospodarki, życia spolecznego i politycznego, kultury i mass mediów przez przyklad swego życia oraz promieniowanie wiara, nadzieją i milościa, w celu ukazania innym Chrystusa (zob. KDK 47-90).

W 2002 roku Kongregacja Nauki Wiary ogłosiła Notę doktrynalnq o niektórych aspektach działalności i postępowania katolików $w$ życiu politycznym ${ }^{12}, \mathrm{w}$ której uwrażliwia katolików na węzlowe problemy współczesnych przemian spoleczno-kulturowych. Zwraca uwage m.in. na zjawiska relatywizmu kulturowego i etycznego. Wskazuje, że imię falszywie pojmowanej tolerancji i pluralizmu żąda się dzisiaj od obywateli wielu państw, w tym także od katolików, aby wyrzekli się zakorzenionej w naturze ludzkiej normy moralnej, według której należy oceniać wszelką koncepcję czlowieka, dobra wspólnego i państwa (nr 1). Kościól pozostawia wprawdzie osąd konkretnych rozwiązań w dziedzinie spoleczno-politycznej każdemu czlowiekowi, ale ma prawo i obowiązek wyrażania moralnych ocen na temat doczesnych rzeczywistości ${ }^{13}$. W tym kontekście Kongregacja podkreśla znaczenie prawidłowo ukształtowanego sumienia, które nie $49-54$

${ }^{12}$ Tekst w języku polskim: „L'Osservatore Romano”. Wydanie polskie. R. 24: $2003 \mathrm{nr} 2 \mathrm{~s}$.

${ }^{13}$ Uprawniony pluralizm doczesnych opcji nie podważa bynajmniej zasad, z których wynika zobowiazanie katolików do zaangażowania w polityke, a odwolujacych się bezpośrednio do chrześcijańskiej nauki moralnej i spolecznej (nr 2). Tamże s. 50 
pozwala katolikom popierać, zwlaszcza w debacie i glosowaniu parlamentarnym, ustaw sprzecznych z moralnością chrześcijańską. Najczęstszym miejscem konfrontacji dzialalności politycznej z zasadami etycznymi jest dzisiaj dziedzina ustaw cywilnych dotyczacych aborcji, eutanazji oraz ochrony embrionu ludzkiego (nr 3). Kościól przypomina wspólczesnym katolikom świeckim postać św. Tomasza Morusa, polityka i wysokiego urzędnika państwowego, człowieka o bezkompromisowym sumieniu i dlatego wybranym na patrona rządzących i polityków.

\section{Zaangażowanie świeckich w życie i działalność Kościoła w Polsce}

Sobór Watykański II zainspirowal katolików świeckich do odkrywania swojej tożsamości i roli w urzeczywistnianiu się Kościoła, przez zaangażowanie w realizację funkcji kaplańskiej, prorockiej i królewskiej Chrystusa (zob. KK 3336). Prymas Polski kard. Stefan Wyszyński byl bardzo ostrożny we wprowadzaniu odnowy soborowej Kościoła w Polsce. Uważał, że wymaga to dhugotrwałej formacji eklezjologicznej duchowieństwa i laikatu. Środowiska laikatu skupione wokól czasopism: „Tygodnik Powszechny”, „Więź” i „Znak”, stale domagaly się szerokiej debaty na temat roli świeckich w Kościele w Polsce. W pewnym zakresie dyskusję tę podjęto na II Polskim Synodzie Plenarnym (1991-1999).

Uczestnictwo katolików świeckich w liturgii koncentruje się wokół niedzielnej Eucharystii. W Polsce jest dość wysoki wskaźnik uczestnictwa katolików w niedzielnej Eucharystii (2003 r. - 46,0\%), ale niepokojącym symptomem jest spadek uczestnictwa w liturgii mlodzieży. Niestety dorośli katolicy rzadko pelnią funkcje liturgiczne (np. ministranta, lektora, kantora lub komentatora), pozostawiając to dzieciom lub mlodzieży. W niektórych parafiach świeccy należą do chóru lub innego zespolu wokalno-muzycznego. W kilkunastu diecezjach w Polsce ustanowiono świeckich szafarzy Eucharystii. Kolejni biskupi diecezjalni powoli wprowadzają tę posługę w swoich diecezjach. W Polsce każdej niedzieli jest kilka telewizyjnych i radiowych transmisji mszy św., ale nie każdy chory może otrzymać w niedzielę Komunię św. Niepokojacy jest fakt, że tylko $20,3 \%$ badanych katolików, przy sprzeciwie 59,7\%, aprobuje udzielanie Komunii św. przez osobę świecką ${ }^{14}$.

Lepiej przedstawia się w Polsce zaangażowanie świeckich w pelnienie funkcji profetycznej. W roku szkolnym 1990-1991 przywrócono w Polsce lekcje

${ }^{14}$ W. Z d an iew ic z: Kościól w Polsce na poczqtku XXI wieku. W: Komisja Duszpasterstwa Ogólnego KEP: Kościól niosqcy ewangelię nadziei. Program duszpasterski Kościola w Polsce na lata $2006-2010$. Katowice 2005 s. 73. 
religii w szkole. Od tego czasu liczba katechetów świeckich sukcesywnie wzrasta. W 2001 r. było w Polsce ponad 19 tys. katechetów świeckich, co stanowiło $52,4 \%$ wszystkich katechetów ${ }^{15}$. Profetyczna misja świeckich jest także realizowana poprzez zawodowe uprawianie teologii. W Polsce świeccy absolwenci wydziałów teologicznych znajdują zatrudnienie glównie w szkolach, poradniach kościelnych i publicznych, mediach katolickich oraz na uczelniach wyższych. Niektórzy świeccy wchodzą w skład zespolów ewangelizacyjnych, prowadzących misje parafialne.

Świeccy w Polsce słabo odpowiadają na propozycję wspóludzialu w funkcji kierowniczej Kościola. Biskupi polscy popieraja tworzenie parafialnych rad duszpasterskich i ekonomicznych, nakazanych przez prawo kanoniczne (kan. $536,537)$. Jednak w większości polskich parafii tych rad nie powolano lub zostaly powolane, ale nie funkcjonuja dobrze, przez co nie spelniaja swojego celu. Parafialne rady do spraw ekonomicznych sa powolywane w momencie podejmowania dużej inwestycji w parafii (np. budowa kościoła lub domu parafialnego). Niestety po zakończeniu inwestycji powyższe rady zazwyczaj same się rozwiązuja. Dokument II Polskiego Synodu Plenarnego wyraża ubolewanie z powodu braku wspólpracy proboszczów ze świeckimi w dziedzinie planowania i realizacji duszpasterstwa ${ }^{16}$.

Ważną dziedzina apostolstwa świeckich jest również działalność charytatywna. Kościół w Polsce stara się być obecnym we wszystkich obszarach ubóstwa, by nieść ludziom potrzebującym pomoc i ulge w cierpieniu. Dzialalność charytatywna w parafiach opiera się na tradycji sięgajacej okresu 1918-1939, a niekiedy XIX wieku. Jednak okres komunizmu spowodowal w Polsce różne perturbacje w zakresie poslugi charytatywnej Kościola. Likwidacja organizacji Caritas, stowarzyszeń kościelnych oraz upaństwowienie prawie wszystkich placówek charytatywnych Kościola w 1950 roku zaowocowało przerwaniem ciaglości pracy charytatywno-socjalnej o charakterze statutowym. Dopiero po 1989 r. Kościól w Polsce mógl powolać organizację Caritas, rejestrować stowarzyszenia chrześcijańskie, a zgromadzenia zakonne i parafie odzyskały osobowość prawnocywilna. Trzeba $z$ uznaniem przyjać, że w trudnych warunkach ekonomicznych spoleczeństwa polskiego instytucjom kościelnym udało się w ciagu 15 lat zorganizować wiele placówek charytatywno-opiekuńczych, a tylko jedna organizacja Caritas chlubi się liczbą 60 tys. wolontariuszy ${ }^{17}$.

\footnotetext{
${ }^{15}$ Zob. A. P o to c k i. Statystyka polskich katechetów. W: Dzisiejszy katecheta. Stan aktualny $i$ wyzwania. Red. J. S t a 1 a. Kraków 2002 s. 33-54. Wzrost liczby katechetów świeckich w stosunku do liczby wszystkich katechetów w Polsce od czasu powrotu religii do szkól przedstawia się następujaco: $1992-41,3 \%, 1996-49,9 \%, 2000-51,4 \%, 2001-52,4 \%$.

${ }^{16}$ II Polski Synod Plenamy (1991-1999). Sól ziemi. Powolanie i poslannictwo świeckich. Warszawa-Poznań 2001 nr 29 s. 152.

${ }^{17}$ Zob. W. Pr z y g o d a: Poshuga charytatywna Kościola w Polsce. Lublin 2004.
} 


\section{Realizacja apostolatu społecznego katolików w Polsce}

Kościól w Polsce po II wojnie światowej, w przeciwieństwie do Kościolów w krajach Europy Zachodniej, funkcjonowal jako Kościól ludowy. Wyrażało się to w nastawieniu uniwersalnym Kościoła i w otwartości na wszystkich obywateli kraju, wierzących i niewierzących. Stając często w obronie uciśnionego przez komunizm narodu, Kościól eksponowal wartości narodowe i przyjmował cechy organizacji religijno-narodowej. Realizowane duszpasterstwo miało charakter masowy i ukierunkowane bylo na przeciętnego katolika. Mniejszą range mialo duszpasterstwo środowiskowe, uwzględniające potrzeby i problemy różnych grup społecznych. Inną cechą Kościoła w Polsce było eksponowanie roli hierarchii przy równoczesnym pomniejszaniu znaczenia laikatu. Prowadziło to do utrwalenia bierności laikatu i zbyt wolnego wprowadzania w życie soborowej eklezjologii wspólnoty. W pierwszych latach po Soborze Watykańskim II hierarchia $z$ dużą nieufnością postrzegala rodzące się oddolnie ruchy religijne. W duchowości dominowalo posluszeństwo Bogu i Kościolowi, pobożność maryjna oraz troska o wychowanie religijne i patriotyczne katolików ${ }^{18}$.

Powolna odnowa soborowa Kościola w Polsce nabrala przyspieszenia po 1980 r. Ruch „Solidarność” spowodowal ogólne ożywienie aktywności obywateli w sferze życia publicznego. Inspirowani katolicką nauką spoleczną katolicy świeccy odważniej zaangażowali się w działalność społeczną i polityczna. Ogłoszony 13 XII 1981 r. przez gen. W. Jaruzelskiego stan wojenny zahamowal na pewien czas rozwój demokracji oraz osłabil dynamikę zaangażowania katolików w życie spoleczne i polityczne. W czasie stanu wojennego Kościól rozwijal pomoc charytatywną dla osób więzionych i internowanych oraz zyskal czas na formację spoleczną katolików świeckich. Lata osiemdziesiate byly czasem rozwoju instytutów wyższej kultury religijnej, klubów inteligencji katolickiej, duszpasterstwa akademickiego oraz katechezy doroslych, prowadzonej glównie w ruchach religijnych.

Przelom 1989 r. zastal Kościól w Polsce jako Kościól masowy, o dużym autorytecie moralnym, pelniący wiele funkcji zastępczych wobec spoleczeństwa i narodu, zaangażowany w dyskusje polityczne, ale nieobecny instytucjonalnie $\mathrm{w}$ życiu publicznym i dosyć autorytarny ${ }^{19}$. Byly to typowe niedostatki Kościola ludowego. Od chwili „przełomu 1989” Kościól w Polsce sukcesywnie uczy się

${ }^{18}$ W. P i wo warski: Kaplani i biskupi - kierownictwo i kościelna komunikacja. W: Kościól i religijność Polaków 1945-1999. Red. W. Z d a n i ew ic z, T. Z e m b r z us ki. Warszawa 2000 s. 12.

${ }^{19}$ P. M a z u rk iw i c z: Recepcja Soboru. W: Kościól i religijność Polaków, s. 36. 
realizacji swojej misji w nowym kontekście spoleczno-kulturowym, demokracji i pluralizmu. Nowa sytuacja społeczno-polityczna kraju stawia Kościól w Polsce wobec nowych problemów i wyzwań (np. troska o wiarygodne prezentowanie swojej misji, troska o swój wizerunek w opinii publicznej itp.), ale budzi także nadzieję na rozwój nowych form obecności Kościola w wolnym i demokratycznym spoleczeństwie, co było niemożliwe w totalitarnym państwie komunistycznym (np. katecheza w szkole, duszpasterstwo wojskowe, nieskrępowane tworzenie organizacji i stowarzyszeń kościelnych, dostęp do mediów publicznych, możliwość pelnego uczestnictwa katolików świeckich w życiu spolecznym, gospodarczym i politycznym itp.).

Aktualny stan zaangażowania polskich katolików w dzialalność spoleczną dobrze opisuje dokument II Polskiego Synodu Plenarnego: „Okres odzyskiwania suwerenności i przemian ustrojowych ukazal siłę polskich katolików, a zarazem obnażył ich słabości. W przelomowym 1989 roku rzesze katolików zamanifestowaly swój sprzeciw wobec komunizmu, oddając w wyborach parlamentarnych glosy na kandydatów opozycji. Później jednak stale zmniejszala się liczba uczestniczacych w aktach wyborczych, w których wyraża się odpowiedzialność za losy państwa" ${ }^{20}$. Wśród przyczyn bierności politycznej Polaków wymienia się: rozczarowanie tempem przemian spolecznych, rozczarowanie poziomem etycznym elit politycznych (egoizm, nepotyzm, korupcja itp.) oraz rozczarowanie spowodowane kosztami spolecznymi transformacji ustrojowej (upadek wielu zakładów pracy; dhugotrwałe, sięgające $20 \%$ bezrobocie).

Słabością elit katolików w Polsce jest także fakt, że nie potrafily one przez 15 lat wolności zbudować trwałej i mocnej partii chadeckiej. Wynika to z braku fachowego przygotowania i doświadczenia przywódców politycznych, gdyż dobre studia polityczne tak w Polsce, jak i na Zachodzie byly dostępne z zasady tylko dla dzieci prominentów komunistycznych. Z kolei hierarchia Kościola w Polsce popierala przez pól wieku oportunizm wobec komunistycznego systemu politycznego, a katolicy świeccy byli wprost zachęcani do odmowy uczestnictwa w partiach politycznych. To wyjaśnia, dlaczego w Polsce stale wydhuża się proces ksztaltowania chrześcijańskich elit politycznych i proces rozwoju dojrzalej demokracji ${ }^{21}$.

Narzędziem polityki uprawianej w duchu chrześcijańskim jest cnota solidarności. Domaga się ona czynnego i odpowiedzialnego udzialu w życiu politycznym wszystkich obywateli, partii politycznych oraz zwiazków zawodowych. Solidarność domaga się przezwyciężania egoizmu i partykularnych interesów,

\footnotetext{
${ }^{20}$ II Polski Synod Plenany: Sól ziemi. Powolanie i poslannictwo świeckich, nr 18 s. 150.

${ }^{21}$ Zob. P. K r y c z k a: Kościól a ksztaltowanie się systemu politycznego w Polsce. W: Wiarygodność Kościola wobec przemian w Polsce. Quo vadis Ecclesia Polonorum? Red. M. R u s e c k i. Pelplin-Lublin 1994 s. 105-114.
} 
przekraczania granicy państw, a także bloków ekonomicznych i wojskowych. Owocem zaś solidarnej polityki jest pokój, będacy upragnionym dobrem ludów i narodów (ChL 42). Paradoksem jest, że „solidarność”, która była szyldem liczącego ponad $10 \mathrm{mln}$ obywateli ruchu spolecznego na poczattku lat osiemdziesiątych XX wieku, dzisiaj stała się w Polsce słowem mało popularnym. Solidarność zostala zastapiona rachunkiem ekonomicznym i ostra walką o przetrwanie na rynku pracy. Jednak są momenty w historii narodu, kiedy solidarność odżywa. W czasie klęsk żywiolowych tak w kraju, jak i za granicą stać biednych Polaków na bogatą pomoc materialną dla potrzebujacych, np. na pomoc dla ofiar powodzi w Polsce w $1997 \mathrm{r}$. zebrano w gotówce ponad $105 \mathrm{mln}$. z $\mathrm{l}^{22}$.

\section{Perspektywy rozwoju apostolstwa świeckich w Polsce}

Ważnym zadaniem Kościoła w Polsce jest troska o pomyślny rozwój apostolatu zrzeszonego katolików świeckich, który lepiej niż apostolat indywidualny wyraża wspólnotową naturę Kościola, a w społeczeństwach mocno zsekularyzowanych zapewnia wyższą skuteczność (zob. ChL 29). Apostolat świeckich w formie zrzeszonej jest realizowany w Polsce przez grupy religijne, stowarzyszenia i ruchy kościelne. Stowarzyszenia chrześcijańskie zostaly w Polsce zlikwidowane przez reżim komunistyczny w 1950 r. Dopiero od 1989 r. stowarzyszenia moga być na nowo rejestrowane w sadach i swobodnie prowadzić dzialalność statutowa. W latach sześćdziesiatych i siedemdziesiatych rozwijaly się natomiast w parafiach grupy nieformalne i kościelne ruchy charyzmatyczne. Do Polski zostaly przeszczepione niektóre ruchy charyzmatyczne $z$ zagranicy ${ }^{23}$, ale powstaly także rodzime ruchy ${ }^{24}$. Rozwój zrzeszeń katolików świeckich mial w Polsce swoje apogeum na przelomie lat siedemdziesiątych i osiemdziesiątych XX wieku. W latach dziewięćdziesiątych nastapila stabilizacja rozwoju zrzeszeń religijnych. Część katolików pozostala w dawnych ruchach nieformalnych, część z nich przylączyla się do powstalych po 1989 r. stowarzyszeń.

W Polsce prowadzi aktualnie dzialalność o zasięgu krajowym lub regionalnym około 150 dużych ruchów i stowarzyszeń chrześcijańskich. Ponadto trudna do oszacowania liczba mniejszych grup funkcjonuje tylko w spolecznościach lokalnych, niekiedy w jednej parafii. Dotychczas odbyly się trzy kongresy krajowe ruchów katolickich (1994, 2000, 2005). Przynależność do grup religijnych, stowarzyszeń i

\footnotetext{
${ }^{22}$ Caritas Polska: Informator Caritas 1998/99. Warszawa 1999 s. 19-37.

${ }^{23} \mathrm{~Np}$. Neokatechumenat, Comunione e liberazione, Odnowa w Duchu Świętym, Focolari, Ruch Szensztacki, Wiara i Światlo i inne.

${ }^{24} \mathrm{~Np}$. Ruch Świato-Życie, zorganizowany przez ks. F. B l a c h n i c k i e g o; Ruch Rodzin Nazaretańskich - założony przez ks. T. D a j c z e r a i inne.
} 
ruchów katolickich w Polsce, według różnych badań, deklaruje 4-7\% katolików (1,5 do 2 mln). Reaktywowana w 1996 r. Akcja Katolicka liczy około 33 tys. czlonków ${ }^{25}$. W 1990 r. powstala Ogólnopolska Rada Ruchów Katolickich, do której aktualnie należą liderzy ponad 70 ruchów katolickich, grupujacych ponad 750 tys. katolików. Celem tej rady jest: promocja dzialalności ruchów katolickich w Kościele i społeczeństwie; rozwój wspólpracy pomiędzy ruchami w zakresie ewangelizacji, apostolstwa i formacji; wspólpraca z Episkopatem Polski, władzami rządowymi i samorządowymi; wspieranie refleksji teologicznej nad zjawiskiem ruchów w Kościele, a także kontakty i wspólpraca międzynarodowa z ruchami katolickimi ${ }^{26}$.

Kościól w Polsce powinien zintensyfikować swoją troskę o rozwój ruchów i stowarzyszeń, gdyż zapelniają one próżnię społeczną istniejącą w wielu parafiach pomiędzy przywódcami religijnymi a dużą spoleczności przeciętnych katolików. Przyczyniają się one do rozwoju życia chrześcijańskiego i budowania wspólnoty w parafii, pogłębienia wiedzy religijnej i duchowości katolików, a także pomagają w ksztaltowaniu sumienia i przekonań moralnych katolików. Zrzeszenia pomagaja katolikom świeckim odkrywać ich powołanie oraz dodają odwagi w realizacji apostolatu we wspólnotach kościelnych i w życiu społecznym. W Polsce przede wszystkim dzięki zrzeszeniom katolików świeckich parafie nie są agencjami usług religijnych, ale dynamicznymi wspólnotami życia chrześcijańskiego. Ruchy i stowarzyszenia chrześcijańskie mają także coraz większy wplyw na życie spoleczne i polityczne. Członkowie zrzeszeń są obecni w mediach, zabieraja głos w ważnych debatach społecznych, np. na temat aborcji, związków homoseksualnych, systemu wychowania dzieci i mlodzieży itp.

Wielkim wyzwaniem dla Kościola w Polsce jest formacja chrześcijańska katolików świeckich. Największym bowiem problemem świeckich w Polsce, podobnie chyba jak w innych krajach, jest rozlam między wiara wyznawana a życiem codziennym (zob. KDK 43). II Polski Synod Plenarny ubolewa na tym, że zbyt slaba jest świadomość religijna katolików świeckich, że martwa jest wiara pozbawiona konsekwencji w życiu rodzinnym, zawodowym i spolecznym ${ }^{27}$. Badania przeprowadzone w 1997 r. w ramach projektu Aufbruch wykazaly, że przekonania religijne Polaków mają maly wplyw na pracę zawodową i postawy polityczne $e^{28}$. Zmiana tego stanu wymaga integralnej i systematycznej formacji

${ }^{25}$ A. S c hu 1z: Teolodzy sq potrzebni ruchom i stowarzyszeniom katolickim. W: Rada Naukowa Konferencji Episkopatu Polski: Kościól w życiu publicznym. Materiaty z VII Kongresu Teologów Polskich. KUL 12-15 LX 2004. Lublin 2004. T. 1 s. 268; zob. J. Ma r i ań sk i: Religijność spoleczeństwa polskiego w perspektywie europejskiej. Kraków 2004 s. 384-387.

${ }^{26}$ Zob. A. P e t row a - W a s i l e w i c z: Leksykon ruchów i stowarzyszeń w Kościele. Warszawa 2000 s. $307-310$

${ }^{27}$ II Polski Synod Plenarny: Sól ziemi. Powolanie i poslannictwo świeckich, nr 26 s. 152.

${ }^{28}$ J. Ma r i a ń s k i: Religijność a życie spoleczne. W: Kościól i religijność Polaków, s. $408-$ 425 
katolików świeckich. Dzisiaj podmiotami formacji chrześcijańskiej katolików w Polsce sa m.in. wydzialy teologiczne, różnorodne grupy religijne oraz media katolickie. Niestety formacja ta obejmuje zbyt maly odsetek polskich katolików. Powszechna formacja świeckich domaga się intensyfikacji funkcji nauczania w szkolach i parafiach ${ }^{29}$, zorganizowania lub rozszerzenia zakresu systematycznej katechezy doroslych ${ }^{30}$, a także tworzenia wśród katolików grup samoksztalceniowych profilowanych na praktyczne przygotowanie do zaangażowania $\mathrm{w}$ dzialalność społeczna, polityczną i kulturalną.

\begin{abstract}
$* * *$
Dyskusja o miejscu i roli świeckich w Kościele przebiega w Polsce o wiele spokojniej niż na Zachodzie. Zapoczątkowana przez Sobór Watykański II reforma Kościoła otworzyla dla świeckich nowe obszary apostolstwa. Jednak w Polsce ze względu na sytuację spoleczno-polityczną w okresie komunizmu laikat nie mógł rozwinać swojej aktywności na forum życia publicznego. $Z$ kolei wystarczająca liczba księży skutecznie utrudniała zaangażowanie świeckich w zakresie życia wewnatrzkościelnego. Zmiany w relacji Kościól - państwo i w relacji kler - świeccy nabraly większej dynamiki dopiero po 1989 r., co przyczynilo się do ożywienia apostolatu świeckich, glównie w sferze życia publicznego.
\end{abstract}

Wybitny specjalista w zakresie teologii laikatu i apostolstwa ks. E. Weron wydal w 1995 r. książkę pt. Budzenie olbrzyma. Polski laikat jest rzeczywiście olbrzymem, ponieważ Polska jest wciąż krajem religijnym. Według badań socjologicznych religijność katolików w Polsce przedstawia się dużo lepiej niż katolików w krajach Europy Zachodniej i Środkowo-Wschodniej. Piętnaście lat doświadczenia wolności i demokracji daja podstawy do stwierdzenia, że nie należy się spodziewać w Polsce w najbliższych latach gwaltownej sekularyzacji. Jednak prawdopodobna jest pelzająca sekularyzacja i powolna dechrystianizacja spoleczeństwa polskiego $^{31}$. Reakcja Kościoła na niekorzystne dla siebie tendencje spoleczne może być tylko przemyślana, zaplanowana i intensywna ewangelizacja. Taka strategia może jednak przynieść powodzenie tylko przy dobrej wspólpracy hierarchii z laikatem. Budzenie drzemiącego laikatu w Polsce jest procesem wciąż potrzebnym, ponieważ większa część laikatu zachowuje postawę bier-

\footnotetext{
${ }^{29}$ Zob. J. B a g r o w i c z: Kościelne wychowanie mlodzieży do życia spoleczno-politycznego. W: Kościól w życiu publicznym. Teologia polska i europejska wobec nowych wyzwań. Materialy $z$ VII Kongresu Teologów Polskich. KUL 1-15 września 2004. Lublin 2004. T. 1 s. 229-246.

${ }^{30}$ Zob. K. Misi a s z k: Polityczno-spoleczny wymiar katechezy doroslych. W: Kościól w życiu publicznym. T. 1 s. 247-257.

${ }^{31} \mathrm{~J}$. Mariań ski: Katolicyzm polski w perspektywie europejskiej: misja czy przystosowanie, czyli z jakq religijnościq do Europy? „Socjologia Religii”. R. 2004: 2 s. 61-69.
} 
ną. Natomiast laikat częściowo przebudzony, reprezentowany przez członków ruchów i stowarzyszeń katolickich, wymaga permanentnej formacji, by na nowo nie zasnąl w obojętności i stagnacji apostolskiej. 